Alma Mater Studiorum - Università di Bologna DEPARTMENT OF ECONOMICS

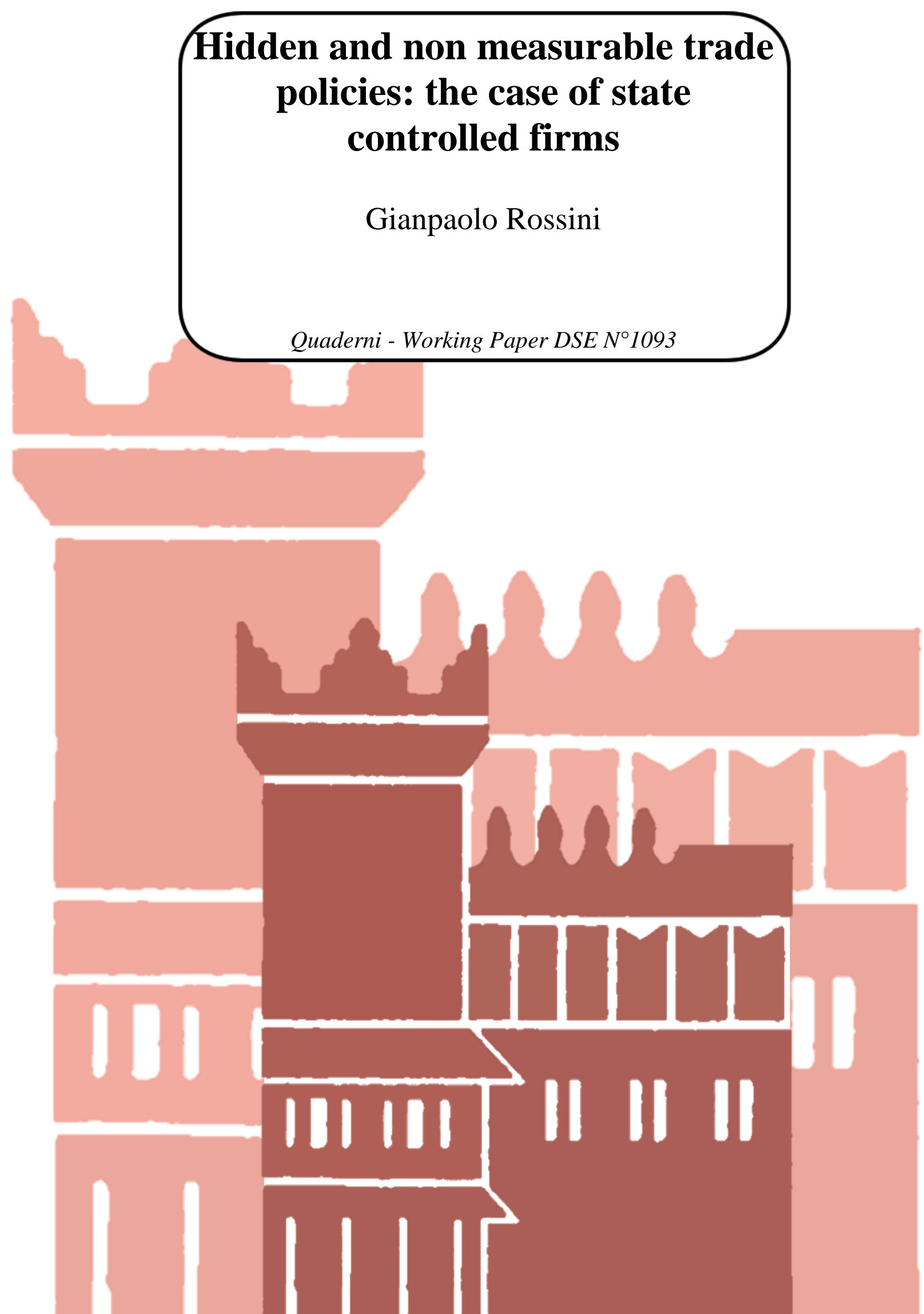




\title{
Hidden and non measurable trade policies: the case of state controlled firms ${ }^{1}$
}

\author{
Gianpaolo Rossini \\ Department of Economics, University of Bologna \\ Strada Maggiore, 45, I-40125 Bologna, Italy \\ Fax ++39.051 .2092664 , Corresponding author: Ph. ++39.051 .2092607$ \\ gianpaolo.rossini@unibo.it
}

November 2016

\footnotetext{
${ }^{1}$ I thank Lehan Jin for for providing data on Chinese products and Carlo Reggiani for several fundamental comments. Moreover, I gratefully acknowledge the financial support of the University of Bologna within the 2016 RFO scheme and the Fondazione Cassa dei Risparmi di Forlì for the support to the project ORGANIMPRE. Finally I thank Andrea Mantovani and the audience of the Thessaloniki ASSET annual conference (9-12 November 2016).
} 


\begin{abstract}
A hot issue in trade negotiations concerns the existence of stateowned firms and state subsidies. Disputes between the US and the EU and the issue of the recognition of the status of a market economy to China are often the epitome of that. In Germany the giant Volkswagen is state controlled, in China almost $1 / 3$ of firms are state controlled and loom in almost all industries often with relevant or even dominant market shares. State enterprises maximize home social welfare. When they export or compete with foreign producers at home their specific objective function make them a useful vehicle for disguised trade policies. We investigate trade cases with oligopoly and state or quasi state owned firms. Increasing returns to scale come into the picture in some instances. Dumping and foreclosure of the domestic market emerge explaining both the possibility of having home prices higher or lower than export prices. Possible counteracting policies can be devised and an example of a production subsidy is presented.
\end{abstract}

JEL Classification: F12, F13, L32.

Keywords: Market asymmetry, dumping, market foreclosure, state owned firms. 


\section{Introduction}

After decades of gradual reductions of tariffs on trade it seems that traditional barriers have been to a large extent removed leaving quite low levels of duties and other taxes on the international exchange of goods and services. Unfortunately the apparent demise of traditional protection tools and the reduction of their weight in international exchanges does not imply that trade barriers have been consigned to history. A large set of disguised, administrative, contingent and strategic obstacles remain in place. Moreover, new protection tools have been devised by governments and, surprisingly enough, by firms in many different ways. In this sense the universe of enterprises cannot be considered as a homogenoeus category. First of all firms show a large variety of objectives according to their ownership and their internal organization. Secondly their economic and environmental performances may radically change according to the market in which they operate. Indeed "the perception that trade policy is no longer relevant arises to a large extent from the inability to precisely measure most non-tariff barriers that have replaced traditional tariffs and subsidies as the primary tools of trade policy" (Goldberg and Pavcnik, 2016). The deepening of economic and institutional integration that has taken place since the establishment of the European Single Market in 1993 had the goal of canceling or at least reducing radically all non tariff barriers that remained in place after the gradual cancellation of traditional custom duties among EU member states. The EU Single Market pioneering program had followers and imitators worldwide. For instance, it inspired several actions carried out by the WTO since its birth in 1995 in its efforts to tackle the surviving thick jungle of nontariff restrictions to trade. Nonetheless, it remains quite awkward to assess the extent of remaining restrictions and uncover the underlying trade policies. Indeed this is quite a complex task: the main tools of nowadays trade policy are not easily quantifiable and their imprint not easily detectable. Some trade policies are often embedded in firms' strategies, making things more fuzzy. Others are only indirectly traceable to government policy measures which do not contain explicit reference to international trade. Further rules are hidden among industrial policy interventions. "The challenges in the measurement of trade policy raise the question of whether the world is truly liberalized, as many believe, or if this impression is misguided and due to our inability to measure the restrictions that really matter. "(Goldberg and Pavcnik, 2016, p.5).

In this context of "nontransparent or hardly measurable" trade policies 
there arise a number of relevant concurrent economics issues related to the presence of state owned firms in industries where firms engage in international trade. How do state owned firms affect international competitive outcomes? How much are stateowned firms the perpetrators of disguised trade policies? Incidentally this question is at the basis of the debate on the recognition to China of the status of market economy (Puccio, 2015; Urdinez and Masiero, 2015). Large and sometimes dominant state owned firms operate in France, Germany and other countries ${ }^{1}$. Here, regulators in many cases may require public dominant firms to pursue domestic social welfare maximization. This simple mode of behaviour may raise a few trade policy concerns. Do specific rulings and public firms provide a trade advantage vis à vis countries where the state presence in the economy is far less relevant? In the case of state owned firms in Europe, China and elsewhere the majority of complaints raised by foreign trade partners regard the presumed dumping policies associated to Government subsidies or simply to "excessively aggressive" policies of public firms. The defendants are noncompetitive practices based on selling goods in foreign markets at prices which are too low partly with respect to domestic prices, partly with respect to costs, but, above all, with respect to foreign competitors. ${ }^{2}$ As a matter of fact, only the second case may be entirely defined as dumping, while the former is a kind of international price discrimination and the third may be simply due to a cost advantage (Malueg and Schwartz, 1994). For the sake of record, we have to say that many competition authorities and trade regulators do not deem international price discrimination a sound (and legitimate) firm strategy. Consequently they tend to condemn it when it goes beyond a reasonable price difference across countries. As a matter of fact there seems to be large room for discretionary assessments and, at the end of the day the question of dumping and related issues require further investigations and explanations. However, the main group of questions is related to issues such as the recognition of the status of market economy to China, the frequent trade disputes between the USA and the UE and to stateowned firms. For instance in China state firms account for about $1 / 4-1 / 3$ of total production and for almost $40 \%$ of stock market

\footnotetext{
${ }^{1}$ In Germany regional public entities (Läender) have a control stake in the giant automaker Volkwagen and other firms. In France this is the case for Renault-Nissan. GM in the Usa has benefited from public capital injections. The dominant presence of public enterprises is quite relevant all over the globe, not just in Communist or formerly Communist countries.

${ }^{2}$ See for instance: Zanardi, (2006) for questions related to dumping definition.
} 
capitalization. In France and Germany the weight of public (or semipublic) firms is large but difficult to precisely assess since many different public entities are involved. In all these cases the influence of government control on firms strategies may be far broader than the sheer state ownership may hint. Finally, there are numerous hybrid firms (where the state has only a share of the equity) and this makes the issue more complex.

As literature (De Fraja and Delbono, 1990; Delbono and Rossini, 1992) and observation suggest, state enterprises are strategically different. They pursue specific objectives which mirror the extent of government control. The most common, yet not unique, assumption in the literature is that stateowned firms maximize domestic social welfare rather than their own market value. However, this objective gets blurred whenever a state firm extends its operations abroad. How should be interpreted the objective of a state company when trade is considered? Obviously, it does not make sense to think of a state owned firm maximizing the social welfare of the foreign countries where it sells. Nor it seems reasonable to assume that a state owned firm maximizes also the profits of all foreign rival producers which sell on the domestic market. Therefore, with trade it seems more realistic to take slightly different avenues. For instance, it may be assumed that state firms maximize domestic social welfare without including the profit of foreign firms exporting their goods to the country of the state owned firms. In addition to that, when exporting the presumption is that state firms simply maximize their operative profit obtained from sales abroad without any concern for the foreign social welfare. This assumption is close to the contribution of Corneo and Jeanne (1994) where they consider the effects of privatizations on welfare and exports of a country where there are private and stateowned firms. Their analysis, confined to linear technology captures only countries net trade positions and does not explore strategic issues leaving many open questions as to the implications for trade and international competition of the existence of state firms strategically exporting to foreign countries.

Our aim in the ensuing pages is to investigate a set of possible trade strategies of state owned firms and to go deeper into the implications for the degree of openness of a country. The purpose is to trace some kind of disguised trade policies carried out by state owned firms. That may make a country behave differently in international markets with respect to partners where public firms are not so relevant and where they are not seen as a tool for strategic trade policies. By the way these policies are not easy to detect if the analysis is conducted with the lens of traditional trade protection. 
We shall see that state owned firms affect the way we should think about reciprocal trade between countries and, in particular, possible partial/total foreclosure, (in)voluntary dumping and asymmetric benefits of trade.

When a country is keen about domestic exporting firms we may figure out state firms as maximizing an augmented social welfare function composed by domestic social welfare plus the profits from exporting. This looks like a strongly domestically oriented perspective for a firm, yet not far from reality of large firms under partial or total government control. As we shall see other objectives may be used by state owned (or quasi state) firms to carry out specific trade policies. A second, yet non secondary, point regards the advantage a country (such as China, but the case could be made also for Germany or the US) may have due to a large internal market. If a large market is somewhat protected it may provide domestic firms "an exorbitant" competitive advantage over rival countries. This advantage may be quite damaging for small market oriented countries. What is the link with stateowned firms? With increasing returns to scale we may figure out that the pricing policy on the domestic market is somehow affected by a regulator who imposes a zero profit condition. The rational firm choice in that case will be to charge the entire fixed cost on the domestic price, while selling abroad a quantity corresponding to the equalization of marginal revenue and marginal cost.

In our analysis based on simple international oligopoly markets we shall see that the strategies of state owned enterprises produce results which are not always in favour of free trade. In certain circumstances, we end up with some kind of dumping strategies. In other cases we obtain domestic market partial (or complete) foreclosure. Indeed we shall see that a market covered by a state firm tends to be foreclosed to foreign competition. As a result trade opening has asymmetric effects simply because of the prevalence in one country of state enterprises or of firms behaving as if they were government controlled. A related question concerns the scenario in which firms face increasing returns to scale. It appears that, if there are international transport costs, the larger country has an advantage even though it does not have any stateowned firm. Again there is no dumping, but the results are quite asymmetric raising the question as to the need to introduce trade policy measures to counteract a (seemingly natural) asymmetry damaging smaller countries.

The concerns of many countries may not only be related to issues of dumping and anti-dumping litigation (as underlined, inter alia, by Urdinez and Masiero, 2015) but to the more subtle incidence of state owned firms and 
their market behaviour. Although strong conclusions should not be based on an oversimplified model, the results of the paper can be productively linked to the debate and some insights about the main concerns of the parties involved be provided. To this purpose we shall also try to devise some counteracting protection policy that could be adopted by a country where firms are all privately run.

To make the case more real, in Appendix B we shall provide some anecdotal evidence based on four instances of goods produced in China and sold everywhere in the world. We compare the retail prices at which those goods are sold in China and in the European Union (EU). The four goods do not aim to provide any significant statistical basis to assess the pricing policies of Chinese exporting firms but simply wish to represent examples of possible behaviour of Chinese firms. As we can see, in two cases there is a presumption that Chinese firms are carrying out a kind of dumping. The difference between the price in China and in the EU is positive and so large that we may classify it as dumping defined as a substantial difference between the domestic and the foreign price. In another instance the difference is not significant excluding any dumping. In a fourth case the price difference is reversed since the export price is significantly higher than the domestic one. We shall define this case as one of partial (or quasi) foreclosure since this price gap may be become a barrier to enrty. Then, we have a wealth of different and somehow opposite results in search of an interpretation. Our main goal is to see whether they may reveal any trace of possible disguised trade policy carried out by firms on behalf of state objectives. Our goal is not to pronounce any verdict neither on China nor on other countries where stateowned firms are popular. We just wish to suggest cases of disguised trade policies that may make a country less open to trade than it appears and, finally, design some suggestive counteracting policies.

The paper is organized as follows. In section 2 we go through a simple duopoly framework of the traditional Brander and Krugman (1983) type. In section 3 we introduce country size asymmetries. In section 4 we go through increasing returns to scale in international oligopolies. In section 5 we see the effects of product differentiation. In section 6 we extend the analysis to a Bertrand framework with a state firm. Section 7 consider a possible example of trade policy while section 8 draws some conclusions. 


\section{An elementary duopoly framework}

We start by considering an international duopoly made by two independent enterprises, whose production is located in two distinct countries $\mathrm{H}$ (Home) and $\mathrm{F}$ (Foreign) separated by transport costs represented by the iceberg parameter $t \in(0,1$ [ (only a share $t$ of the value produced in one country can reach the foreign market $)^{3}$. The firms manufacture a homogeneous good and partially follow the Cournot tenet. Each firm faces two simple linear demand functions ${ }^{4}$ in the two markets

$$
\begin{aligned}
& p_{H}=a_{H}-q_{H}-t q_{F X} \\
& p_{F}=a_{F}-q_{F}-t q_{H X}
\end{aligned}
$$

where $p_{H}$ and $p_{F}$ are the market prices of the good sold in market $H$ and $F, a_{H}$ and $a_{F}$ are the respective market size, $q_{H}, q_{F}$ are the sales of the two firms in their own countries while $q_{H X}, q_{F X}$ are their exported outputs. The profit of the state owned firm based in country $\mathrm{H}$ is made by domestic plus foreign profit

$$
\pi_{H S}=\pi_{H}+\pi_{H X}
$$

where

$$
\pi_{H}=p_{H} q_{H} \quad \text { and } \quad \pi_{H X}=t p_{F} q_{H X}
$$

since we assume, for the sake of simplicity, that the production cost is null. The consumer surplus in country $\mathrm{H}$ is

$$
c s_{H}=\frac{\left(a_{H}-p_{H}\right)\left(q_{H}+t q_{F X}\right)}{2}
$$

while the profit of the foreign private firm is:

$$
\pi_{F}=p_{F} q_{F}+t p_{H} q_{F X} .
$$

Indeed, the firm based in $\mathrm{H}$ is state owned and maximizes the social welfare of home. Then, social welfare does not include the profit of the foreign firm selling in $\mathrm{H}$. Moreover, the state owned firm exports in the market of the rival and sets its quantities by maximizing profit on the foreign market. Unlike

\footnotetext{
${ }^{3}$ For a defintion and an application see Rossini (2007).

${ }^{4}$ If we consider non linear concave demand fucntions we may end up with a market which is partially foreclosed.
} 
the $\mathrm{H}$ firm, the foreign firm located in $\mathrm{F}$ is a private profit seeking enterprise and operates in both $\mathrm{F}$ and $\mathrm{H}$ markets by setting optimal Cournot quantities. Let's define home social welfare, maximized by $\mathrm{H}$ firm, as:

$$
s w_{H}=c s_{H}+\pi_{H} .
$$

In this simple framework we can write the following:

Lemma 1 Two firms export to their rivals' markets. One maximizes home social welfare and profit abroad. The foreign rival is a pure Cournot profit seeker. In equilibrium, the domestic market of the stateowned firm is foreclosed to the foreign rival that does not export.

Proof. For the sake of simplicty we assume symmetric markets, i.e., $a_{H}=a_{F}=a$. We simultaneously solve for the following focs:

$$
\left\{\begin{array}{c}
\frac{\partial \pi_{F}}{\partial q_{F}}=0=a-2 q_{F}-q_{H X} t \\
\frac{\partial \pi_{F}}{\partial q_{F X}}=0=t\left(a-q_{H}-2 q_{F X} t\right) \\
\frac{\partial s w_{H}}{\partial q_{H}}=0=a-q_{H} \\
\frac{\partial \pi_{H X}}{\partial q_{H X}}=0=t\left(a-q_{F}-2 q_{H X} t\right)
\end{array}\right\}
$$

and get the equilibrium quantities:

$$
q_{F}^{*}=\frac{a}{3} ; \quad q_{F X}^{*}=0 ; \quad q_{H}^{*}=a ; \quad q_{H X}^{*}=\frac{a}{3 t} .
$$

Socs are always met as the stability requirement over the sign of the principal minor of the determinant of the Hessian matrix. Equilibrium social welfare and consumer surplus are:

$$
\begin{aligned}
\pi_{F}^{*} & =\pi_{H}^{*}=\frac{a^{2}}{9} \\
c s_{H}^{*} & =\frac{a^{2}}{2} \geq c s_{F}^{*}=\frac{2 a^{2}}{9} \\
s w_{H}^{*} & =\frac{a^{2}}{2} \geq s w_{F}^{*}=\frac{a^{2}}{3} .
\end{aligned}
$$

If we include in $s w_{H}^{*}$ the profit of the $H$ firm in country $F$ we get an augmented version of domestic welfare, i.e., $s w_{H N}^{*}=\frac{11 a^{2}}{18} \geq s w_{H}^{*}$.

It can be easily verified that the two firms obtain the same profit when operating in country F, i.e., $\frac{a^{2}}{9}$. Then, country H, possessing the stateowned 
firm, enjoys a higher consumer surplus (in country $\mathrm{H}$ the market price is zero and equal to the marginal cost of the domestic firm) and the same national producer surplus of the other country, since the $\mathrm{H}$ firm maximizes profit when operating abroad. Therefore, $\mathrm{H}$ enjoys a higher social welfare. The interesting outcome is that in country $\mathrm{H}$ the market is foreclosed to the foreign producer. The funny thing is that this occurs without any prohibitive tariff or discriminatory measure in favour of the domestic producer. In other words we do not need any trade policy to keep the door of the domestic market shut to foreign competitors. This is the first example we provide of a closed market in the absence of any trade policy.

If we compare this case with the control solution represented by a standard Cournot international duopoly with two symmetric profit seeking firms, we can write the following

Proposition 1 Let"s compare the asymmetric case containing a stateowned firm in $H$ with the standard symmetric Cournot case. The country with the state owned firm enjoys a larger social welfare than in the symmetric Cournot case, while the other country whose firm is foreclosed has a lower welfare. At the global tier social welfare is higher with two profit seeking Cournot firms. Yet the global consumer surplus is higher even with the presence of just one state owned firm which maximixes profits abroad.

Proof. Let's continue with the above framework. In the naive Cournot symmetric case we have:

$$
\begin{gathered}
q_{F}^{*}=q_{H}^{*}=\frac{a}{3} ; \quad q_{H X}^{*}=q_{F X}^{*}=\frac{a}{3 t} . \\
p_{H}^{*}=p_{F}^{*}=\frac{a}{3}
\end{gathered}
$$

Mind you that with the stateowned firm in $\mathrm{H}$ and the profit seeking firm in $\mathrm{F}$ the equilibrium market price in $\mathrm{H}$ is zero $\left(p_{H}^{*}=0\right)$ while in contry $\mathrm{F}$ is the same as in the case of the symmetric Cournot international duopoly $\left(p_{F}^{*}=\frac{a}{3}\right)$.

$$
\begin{aligned}
\pi_{F}^{*} & =\pi_{H}^{*}=\frac{2 a^{2}}{9} \\
s w_{H}^{*} & =s w_{F}^{*}=\frac{4 a^{2}}{9} \\
c s_{H}^{*} & =c s_{F}^{*}=\frac{2 a^{2}}{9} .
\end{aligned}
$$


Let's compare the corresponding equilibrium welfare and consumer surplus contained in the Lemma 1 proof. Simple inspection suggests that social welfare turns out to be larger in symmetric Cournot for country $\mathrm{F}$ but lower for country $\mathrm{H}$ with respect to the asymmetric case with a state owned firm in country $\mathrm{H}$. If we think globally we may see that

$$
\left(c s_{H}^{*}+c s_{F}^{*}\right)_{\text {SymmCournot }}-\left(c s_{H}^{*}+c s_{F}^{*}\right)_{\text {AsymmStateFirm }}=-\frac{5 a^{2}}{18} .
$$

while

$$
\left(s w_{H}^{*}+s w_{F}^{*}\right)_{\text {SymmCournot }}-\left(s w_{H}^{*}+s w_{F}^{*}\right)_{\text {AsymmStateFirm }}=-\frac{5 a^{2}}{18} .
$$

But if we use the broader version of social welfare in $\mathrm{H}$ in the case of the state firm we have

$$
\left(s w_{H}^{*}+s w_{F}^{*}\right)_{\text {SymmCournot }}-\left(s w_{H N}^{*}+s w_{F}^{*}\right)_{\text {AsymmStateFirm }}=\frac{8 a^{2}}{9}-\frac{17 a^{2}}{18}=-\frac{1 a^{2}}{18}
$$

which means that the global social welfare is higher with the state firm.

Foreclosure occurs also with product differentiation in the Cournot mode of competition (see Appendix C) and is quite a general outcome. As we have seen, this case leads to prices which differ across countries. The country with the state owned firm has its market foreclosed to foreign competitors and a lower market price. In other words there is no dumping yet a limitation of competition in the market of the country with the state owned firm. This may have influential political economy implications which may make this setting quite stable and sustainable in terms of domestic political consensus.

A simple corollary may be derived from the previous results just by considering the effects of changes in country size. In the traditional Cournot framework there is a positive effect of increasing market size of a country on the social welfare of the foreign partner. However, when in one country the pretrade market is covered by a state firm this effect disappears turning the reciprocal benefits of trade opening into quite asymmetric effects. This can be grasped in the following:

Corollary 1 As the size of the market of country $H$ increases the social welfare of country $F$ does not change since the firm of country $F$ is always foreclosed, while in the traditional Brander-Krugman (1983) Cournot model of trade the profits of firm $F$ grow (and hence sw $w_{F}$ ) when the partner country gets larger. 
Proof. From the two previous proofs, simply assuming that the demand in country $\mathrm{H}$ is

$$
\begin{aligned}
p_{H} & =a_{H}-q_{H}-t q_{F X} \\
p_{F} & =a_{F}-q_{F}-t q_{H X}
\end{aligned}
$$

we can see that

$$
s w_{F}^{*}=\frac{b^{2}}{3} \text { and } \frac{\partial s w_{F}^{*}}{\partial a_{H}}=0 .
$$

The above results show that opening trade between a country where there is a prevalence of state owned firms and another country with profit seeking firms generate effects which may make trade benefits quite asymmetric and somewhat unpleasant, calling for some commercial policy. The main obstacle to trade is the sort of foreclosure generated by a domestic pricing strategy adopted by the state owned firm. As a result the domestic market turns out to be almost (or at least hardly) uncontestable by foreign firms. The only possibility to react to the barrier represented by foreclosure should be for a domestic private firm accept a zero proft condition at home. We shall see later in section 6 that some counteracting policy can be devised.

More catching results emerge if we extend the analysis to the intriguiging case of increasing returns to scale we shall see in the next section.

\section{Increasing returns to scale}

Further interesting cases may be suggested by increasing returns technology. The scenario is similar to the one of the section above. We consider again two firms located in country $\mathrm{F}$ and $\mathrm{H}$ producing with concave costs due to a fixed commitment. We figure out a mode of behaviour similar to that of a stateowned firm or to a (quasi) regulated firm. We should bear in mind that regulation in several cases may lead to results similar to state ownership ${ }^{5}$. Let us see why. Everytime we examine a firm with increasing returns to scale (irs) we wonder what kind of pricing policy it may adopt. The theory of contestable markets (Baumol, Panzar and Willig, 1982) suggests a market solution which is close to the planner objective, i.e., average cost pricing. A firm enjoing irs should be either playing in a contestable environment, mostly

\footnotetext{
${ }^{5}$ See for instance Bauer (2005) and Decker (2014).
} 
when fixed costs are not sunk, or be subject to some kind of regulation or stateownership whenever fixed costs are sunk. In all cases the firm may end up with a zero profit condition as the best strategy of conduct on the domestic market where regulation is supposedly enforced. In this case the stateowned firm and the corresponding profit seeking firm behave in almost the same way $^{6}$. Trade may change and enrich the picture since it relaxes the domestic market constraint when a firm sells abroad. As a matter of fact, there is the possibility of making profits in the foreign market where regulation is absent or different with respect to the domestic market. Regulation or simply the public monitoring of the firm in the domestic market may add to the rationale of adopting a policy of average cost pricing. If that is the case, in the domestic market the firm covers the fixed cost generating irs, while in the foreign market it maximizes profits without the fixed cost burden. This behaviour is replicated by the rival if the framework is symmetric. At the end of the day we are left with two markets in which a domestic zero profit firm competes with a foreign profit seeking firm. This way of modeling irs and trade differs from traditional models in the literature originated from Helpman (1984) and Krugman (1980) where the strategies of firms are the same regardless of the market where they operate. Before going through the proposition describing the equilibrium setting, we have to describe the firms' behaviour in a more detailed way. First each firm decides the quantity to sell by setting profits to zero on the domestic market. Therefore, the firm is ready to sell at a price which is equal to the average cost. Then, each firm observes the quantity of the rival on the relative market and sets the optimal quantity to export by maximizing profits abroad. Given this sequence of interactions, the equilibrium setting can be described in the following:

Proposition 2 In a symmetric international duopoly with irs each firm charges fixed costs on the domestic sales making zero profits at home while maximizing profit in the foreign market. Prices are larger than average costs and allow non negative profits derived from exports. When markets differ in size the market price is higher in the larger market. This gives rise to a kind of "involuntary dumping".

\footnotetext{
${ }^{6}$ See Bauer (2005) and Decker (2014).
} 
Proof. Let us consider separately domestic and export profits, first for the domestic firm, secondly for the foreign firm:

$$
\begin{aligned}
\pi_{H} & =p_{H} q_{H}-f \text { domestic } \\
\pi_{H X} & =t p_{F} q_{H X} \text { foreign } \\
\pi_{F} & =p_{F} q_{F}-f \text { domestic } \\
\pi_{F X} & =t p_{H} q_{F X} \text { foreign }
\end{aligned}
$$

where $f$ stands for fixed cost. The firms simultaneously set the quantities in their respective domestic markets by charging the fixed cost on the domestic balance sheet and setting domestic profits equal to zero. Then, they maximize profits on the foreign market. The equilibrium quantities are:

$$
\begin{aligned}
& q_{H}^{*}=\frac{1}{4}\left(a-\sqrt{\frac{\left(a^{2}-4 f\right)^{2}}{a^{2}}+} \frac{4 f}{a}\right) ; q_{H X}^{*}=\frac{b^{2}-4 f}{2 b t} \\
& q_{F}^{*}=\frac{1}{4}\left(b-\sqrt{\frac{\left(b^{2}-4 f\right)^{2}}{b^{2}}+} \frac{4 f}{b}\right) ; q_{F X}^{*}=\frac{a^{2}-4 f}{2 a t}
\end{aligned}
$$

Prices are:

$$
p_{H}^{*}=\frac{1}{4 a}\left(a+\sqrt{\frac{\left(a^{2}-4 f\right)^{2}}{a^{2}}}+4 f\right) ; p_{F}^{*}=\frac{1}{4 b}\left(b+\sqrt{\frac{\left(b^{2}-4 f\right)^{2}}{b^{2}}}+4 f\right) .
$$

profits are zero on the domestic market, i.e., $\pi_{H}^{*}=\pi_{F}^{*}=0$, while abroad they are:

$$
\pi_{H X}^{*}=\frac{\left(b^{2}-4 f\right)\left(b\left(b+\sqrt{\frac{\left(b^{2}-4 f\right)^{2}}{b^{2}}}\right)+4 f\right)}{8 b^{2}}
$$

and

$$
\pi_{F X}^{*}=\frac{\left(a^{2}-4 f\right)\left(a\left(a+\sqrt{\frac{\left(a^{2}-4 f\right)^{2}}{a^{2}}}\right)+4 f\right)}{8 a^{2}} .
$$

Then, we can easily see that

$$
\frac{\partial p_{F}^{*}}{\partial b} \geq 0 \text { if } b \geq 2 f
$$

which is the condition to have nonnegative exports by $H$ and, in a similar vein, for the other firm. This confirms the result of "involuntary dumping" 
whereby the larger country exports a good whose price abroad is lower than at home. Moreover we can easily see that, with symmetric markets, the price is equal to the average cost:

$$
\begin{aligned}
& A C_{H}=\frac{f}{q_{H}^{*}+q_{H X}^{*}}=\frac{4 a b f t}{2 a\left(b^{2}-4 f\right)-a b \sqrt{\frac{\left(a^{2}-4 f\right)^{2}}{a^{2}}} t+b\left(a^{2}+4 f\right) t} \leq p_{H}^{*} \\
& A C_{F}=\frac{f}{q_{F}^{*}+q_{F X}^{*}}=\frac{4 a b f t}{2 b\left(a^{2}-4 f\right)-a b \sqrt{\frac{\left(b^{2}-4 f\right)^{2}}{b^{2}}} t+a\left(b^{2}+4 f\right) t} \leq p_{F}^{*} .
\end{aligned}
$$

If market $F$ is strictly larger than $H(b>a)$ the market price of $F$ is higher than that of $H$.

However, the profit of the firm residing in the larger market is lower since it exports less than the firm of the smaller market:

$$
p_{H}^{*}<p_{F}^{*} ; q_{H X}^{*}>q_{F X}^{*} ; q_{H}^{*}>q_{F}^{*} ; \pi_{H X}^{*}>\pi_{F X}^{*} .
$$

The outocome is interesting on several grounds. First of all it says that the larger market displays higher prices. These prices are larger than marginal costs and also average costs. The result of the above proposition may be used to explain our funny "involuntary dumping". This kind of trade strategy may be that adopted by some Chinese firms simply because of their size and economies of scale. Notice that this effect may become more severe in the presence of excess capacity ${ }^{7}$. Nonetheless, all that may benefit the firm residing in the smaller market which will gain more from trade than the rival from the large country. This replicates a recurrent trade result maintaining that small countries benefit more than large ones from free trade. The resemblance of this outcome with a contestable market equilibrium may let to infer that this equilibrium is somewhat desirable. As a matter of fact it may be so. But in case of asymmetry in country size the smaller country may be induced to introduce defensive policies against some kind of dumping even though this sort of dumping is coupled to the opportunity to access a larger market. Nonetheless, a contingent antidumping measure may be devised to compensate for differences in average costs due to different scales of production. Again, if the market of the larger country is not protected

\footnotetext{
${ }^{7}$ This issue is developed in the companion paper (Rossini, 2016).
} 
by barriers, it provides opportunities for the firm of the smaller country that ends up by making larger profits from exports than the firm of the large country selling in the small country.

\section{Product differentiation and price competi- tion}

Now we go through the analysis of product differentiation and price competition and see how trade and asymmetric behaviour of firms lead to results that parallel evidence on prices across countries and in particular China and western countries. As before two firms based in country $\mathrm{F}$ and $\mathrm{H}$ respectively produce a differentiated good that they export to each others' market by setting the price of their own good. The indirect demand functions are:

$$
\begin{aligned}
p_{H} & =a-q_{H}-s t q_{F X} \\
p_{F} & =b-q_{F}-s t q_{H X} \\
p_{H X} & =b-s q_{F}-t q_{H X} \\
p_{F X} & =a-s q_{H}-t q_{F X}
\end{aligned}
$$

while the direct demand functions

$$
\begin{aligned}
q_{H} & =\frac{p_{H}+a(s-1)-s p_{F X}}{s^{2}-1} \\
q_{F} & =\frac{p_{F}+b(s-1)-s p_{H X}}{s^{2}-1} \\
q_{F X} & =\frac{-s p_{H}+a(s-1)+p_{F X}}{t\left(s^{2}-1\right)} \\
q_{H X} & =\frac{p_{H X}+b(s-1)-s p_{F}}{t\left(s^{2}-1\right)} .
\end{aligned}
$$

Profit functions are

$$
\begin{aligned}
\pi_{H} & =p_{H} q_{H}-f \geq 0 \\
\pi_{F} & =p_{F} q_{F}-f \geq 0 \\
\pi_{H X} & =t p_{H X} q_{H X} \geq 0 \\
\pi_{F X} & =t p_{F X} q_{F X} \geq 0 .
\end{aligned}
$$


As we can see the fixed cost is charged on the domestic profit. We assume that firms on their domestic markets simply break even. On the foreign market they set their price maximizing profits. Then the solution for the equilibrium prices comes from the following first order conditions (FOCs) under the constraints (5) set above

$$
\left\{\begin{array}{c}
\frac{\partial \pi_{F X}}{\partial p_{F X}} \\
\frac{\partial \pi_{H X}}{\partial p_{H X}} \\
\pi_{H} \\
\pi_{F}
\end{array}=0\right.
$$

The equilibrium prices are:

$$
\begin{aligned}
p_{H X}^{*} & =-\frac{b(s-1)((2+s) s-4)+s \sqrt{b^{2}\left(s+s^{2}-2\right)-8 f\left(2-3 s^{2}+s^{4}\right)}}{4\left(s^{2}-2\right)} \\
p_{F X}^{*} & =-\frac{a(s-1)((2+s) s-4)+s \sqrt{a^{2}\left(s+s^{2}-2\right)-8 f\left(2-3 s^{2}+s^{4}\right)}}{4\left(s^{2}-2\right)} \\
p_{H}^{*} & =\frac{a\left(s+s^{2}-2\right)-\sqrt{(s-1)\left(a^{2}(s-1)(2+s)^{2}-8 f(1+s)\left(s^{2}-2\right)\right)}}{2\left(s^{2}-2\right)} \\
p_{F}^{*} & =\frac{b\left(s+s^{2}-2\right)-\sqrt{(s-1)\left(b^{2}(s-1)(2+s)^{2}-8 f(1+s)\left(s^{2}-2\right)\right)}}{2\left(s^{2}-2\right)}
\end{aligned}
$$

From the above results and ensuing proof we can establish the following:

Proposition 3 Firms face increasing returns to scale, adopt a Bertrand mode of behaviour abroad, differentiate their products and decide to break even on their domestic market where they charge the fixed costs. Each firm sells at a lower price a larger quantity on the foreign market giving rise, again, to a reciprocal "involuntary" dumping partly similar to the original Brander - Krugman type. If countries are not symmetric in terms of size the firm of the larger country adopts a more aggressive dumping (lower price) in the foreign country than its rival but sells less. The rival firm sells more in the larger (foreign) country and makes higher profits.

Proof. Just calculate the difference between the two prices made by the two firms in their respective foreign markets: 


$$
\begin{aligned}
p_{F}-p_{F X}= & \frac{1}{4\left(s^{2}-2\right)}\left(a(s-1)(s(s-2)-4)+2 b\left(s^{2}+s-2\right)+\right. \\
& +s \sqrt{(s-1)\left(a^{2}(s-1)(2+s)^{2}-8 f(1+s)\left(s^{2}-2\right)\right)}- \\
& -2 \sqrt{(s-1)\left(b^{2}(s-1)(2+s)^{2}-8 f(1+s)\left(s^{2}-2\right)\right)}
\end{aligned}
$$

which is always non negative. Some numerical simulations reported in Appendix A provide a description of the content of the above Proposition.

The above proposition somehow generalizes the previous results to a Bertrand cum-differentiation scenario. Dumping now becomes more detailed. It involves selling in the foreign market at a lower price in the presence of a domestic firm which sets a higher price. This effect may be exacerbated by size asymmetries among countries.

\section{Bertrand competition and foreclosure}

Is there still a case for foreclosure with Bertrand competition? The question matters since Bertrand competition is associated to large capacity that allows firms to make real the "Bertrand threat" of driving prices down up to marginal costs. This question is worth answering in times of overcapacity due, for instance, to prolonged recessions or structural changes. In some industries we know that there is structural (or chronic) overcapacity making Bertrand much more than a sheer academic toy. If we introduce differentiation the marginal cost pricing equilibrium fades and we expect the Bertrand threat not to lead to zero profits since firms are shielded by their product specificity. To investigate these issues, we consider a market in which a stateowned firm operates (market $\mathrm{H}$ ). Do we still have foreclosure? The answer comes from the ensuing proposition where we examine the equilibrium in a Bertrand setting of firms facing constant returns.

Proposition 4 With Bertrand competition, differentiation, a state owned or any firm with the goal to break even on the domestic market, foreclosure does not obtain (or, due to the large difference between the domestic and the foreign price we may say that there is only "partial foreclosure"). The state firm sells at home at a price lower than abroad, while the rival firm, which maximizes profits, adopts a dumping strategy 
Proof. Direct demand functions are

$$
\begin{aligned}
q_{H} & =\frac{p_{H}+a(s-1)-s p_{F X}}{s^{2}-1} \\
q_{F X} & =\frac{s p_{H}-a(s-1)-p_{F X}}{-t\left(s^{2}-1\right)} \\
q_{F} & =\frac{p_{F}+b(s-1)-s p_{H X}}{s^{2}-1} \\
q_{H X} & =\frac{s p_{F}-b(s-1)-p_{H X}}{-t\left(s^{2}-1\right)}
\end{aligned}
$$

Let us define the profit functions

$$
\begin{aligned}
\pi_{H} & =p_{H} q_{H} \\
\pi_{F} & =p_{F} q_{F} \\
\pi_{H X} & =t p_{H X} q_{H X} \\
\pi_{F X} & =t p_{F X} q_{F X}
\end{aligned}
$$

and the optimal program is

$$
\left\{\begin{array}{c}
\frac{\partial \pi_{F}}{\partial p_{F}} \\
\frac{\partial \pi_{F X}}{\partial p_{F X}} \\
\pi_{H} \\
\frac{\partial \pi_{H X}}{\partial p_{H X}}
\end{array}=0\right.
$$

As it can be seen the home firm has a zero profit goal which corresponds to the maximum consumer surplus from the domestic good in the presence of a foreign firm supplying a differentiated good. Equilibrium variables are

$$
\begin{aligned}
q_{H X}^{*} & =\frac{b}{\left(2+s-s^{2}\right) t} ; q_{F}^{*}=\frac{b}{2+s-s^{2}} ; q_{H}^{*}=\frac{a(2+s)}{2(1+s)} ; q_{F X}^{*}=\frac{a}{27+2 s t} \\
p_{H}^{*} & =0 ; p_{F X}^{*}=\frac{1}{2} a(1-s) ; p_{H X}^{*}=b\left(1+\frac{1}{s-2}\right) ; p_{F}^{*}=b\left(1+\frac{1}{s-2}\right) \\
\pi_{H X}^{*} & =-\frac{b^{2}(s-1)}{(s-2)^{2}(1+s)}=\pi_{F}^{*} ; \pi_{H}^{*}=0 ; \pi_{F X}^{*}=-\frac{a^{2}(s-1)}{4(1+s)}
\end{aligned}
$$


Moreover:

$$
\begin{aligned}
p_{F}^{*}-p_{F X}^{*} & =b\left(1+\frac{1}{s-2}\right)+\frac{1}{2} a(s-1) \gtreqless 0 \\
p_{H}^{*}-p_{H X}^{*} & =-b\left(1+\frac{1}{s-2}\right) \leq 0 \text { (partial foreclosure) } \\
q_{H}^{*}-q_{H X}^{*} & =\frac{2 b+a\left(s^{2}-4\right) t}{2(s-2)(1+s) t} \\
q_{F}^{*}-q_{F X}^{*} & =-\frac{a(s-2)+2 b t}{2(s-2)(1+s) t}
\end{aligned}
$$

Here, we provide some simulation to support the above proposition:

$$
\text { Sim. I Sim. II }
$$

$\begin{array}{lll}p_{F}^{*} & 1.67 & \\ p_{H}^{*} & 0 & \\ p_{F X}^{*} & 1.00 & 2.00 \\ p_{H X}^{*} & 1.67 & \\ q_{H X}^{*} & 6.61 & \\ q_{F X}^{*} & 3.97 & 7.94 \\ q_{H}^{*} & 7.78 & 15.56 \\ q_{F}^{*} & 4.63 & \\ \pi_{H X}^{*} & 7.72 & \\ \pi_{H}^{*} & 0 & \\ \pi_{F X}^{*} & 2.78 & \\ \pi_{F}^{*} & 7.72 & \\ p_{F}^{*}-p_{F X}^{*} & 0.67 & -0.33 \\ p_{H}^{*}-p_{H X}^{*} & -1.67 & -1.67\end{array}$

TABLE 1

Sim. I parameters: $\mathrm{a}=\mathbf{1 0}, \mathrm{b}=10, \mathrm{~s}=0.8, \mathrm{t}=0.7$

Sim. II parameters: $\mathrm{a}=\mathbf{2 0}, \mathrm{b}=10, \mathrm{~s}=0.8, \mathrm{t}=0.7$

As it can be seen from (6) complete foreclosure does not obtain, even though we may have a kind of "partial" foreclosure, i.e., a domestic price lower than the export price. This result differs from Cournot, but still points to a firm strategy which is the opposite of dumping and may be able to 
explain why we observe prices which are lower at home than on the export market. Of course, this kind of "partial foreclosure" or reverse dumping is quite remarkable and it may call for some trade policy. As for the issues examined in previous sections the extent of country asymmetries may make the outcomes harder to sustain. However, it is not always the case that the damaged country is the small country.

\section{What kind of trade policy?}

As it happens frequently in the new theories of trade the policy prescriptions vary quite a lot according to specific market structure and strategies adopted by firms, for instance Cournot versus Bertrand, private vs. stateowned firms. In the above sections we have seen a bunch of different results. First, the market price in the country with the stateowned firm is lower than in the foreign country where the domestic firm sells maximizing profit. Secondly, the market of the stateowned firm is foreclosed (totally in the case of Cournot and partially in the case of Bertrand) to the foreign firm. In a different scenario, with increasing returns to scale, examined only with a Cournot mode of interaction, there is a size effect whereby the larger country tends to have higher prices and adopt dumping abroad. Clearly these different results exclude the possibility of featuring a unique "simple" dumping or foreclosure case to be counteracted by a catchall sheer "antidumping" duty or anything close to it. Nonetheless, we may try to devise specific commercial policies to improve upon the welfare of the country which may be hurt by foreclosure or by dumping, whatever their origin even if it is hard either for a regulator or a trade policy maker to trace a market outcome to its strategic determinants and design "proper" commercial policies.

Then, what kind of trade policy may be envisaged? Given the wide variety of specific scenarios, it may seem that only a piecemeal approach is feasible. Once again we must notice that the strategies we have seen above are carried out by firms and are quite hard to single out and measure.

We proceed confining our analysis of possible trade policies to the specific case of foreclosure.

As seen above a foreign profit seeking firm may be kept out of a country where the incumbent firm is stateowned. In such a case the foreign country may wish to help its firm to penetrate the market from which it is excluded. 
What kind of rationale should inspire an action to promote the export by the domestic firm? The policy may actually come from the consideration of a broadly encompassing social welfare function that a government is supposed to maximize. This goal may depart from traditional social welfare functions. A government may simply want to provide its national firms a basic support to sell in all foreign markets. Why? The reason has at least a twin ground. First, governments know that exporting is a healthy strategy since it stimulates innovation and competitiveness with considerable feedback on the entire national economy. Secondly, the foreign stateowned firm sells in the market of the profit seeking rival which may solicit the government to guarantee reciprocity in terms of trade opportunities. Therefore, a trade policy to counteract foreclosure should neither be dictated by mercantilism nor by any general macroeconomic reason, nor related to usual social welfare targets. It may simply be oriented to guarantee an efficiency boost for exporting domestic firms and to obtain reciprocity standards.

On the basis of these considerations, we provide an example of a possible policy out of the large cluster of measures that may be adopted.

In this sense we open the way to a fresh analyisis of counteracting trade policy measures devised to reciprocity standards when foreign firms have organization structures and market strategies that are deemed asymmetric with respect to domestic firms.

Confining to stateowned firms induced foreclosure, we can devise a simple trade protection policy that allows a country to compensate the disadvantage that emerges with respect to the foreign country that has the stateowned firm. Perhaps, the simplest measure that could be set in place is a subsidy.

We summarize some of the features of this protective policy in the following proposition:

Proposition 5 A per unit of output production subsidy may be set by the country home of the profit maximizing firm. The goal of the goverment is to let the profit seeking firm be internationally as competitive as the stateowned foreign firm and export the same quantity. In such a case the subsidy increases with the size of the market and decreases as the foreign stateowned firm costs increase.

Proof. We use a more general framework with respect to the model of previous sections introducing heterogeneous costs across firms. Therefore, while the demand functions remain the same, the profit functions now look 
as follows:

$$
\begin{gathered}
\pi_{F}=\left(p_{F}-c_{F}\right) q_{F}+t\left(p_{H}-c_{F}\right) q_{F X} \\
\pi_{H}=\left(p_{H}-c_{H}\right) q_{H}+t\left(p_{F}-c_{H}\right) q_{H X}
\end{gathered}
$$

where $c_{F}$ and $c_{H}$ are the average costs of production of the two firms $F$ and $H$. If firm $F$ is a social welfare maximizer while firm $H$ is a profit seeker the equilibrium quantities of the Cournot game are:

$$
\begin{aligned}
q_{H} & =\frac{1}{3}\left(a+c_{F}-2 c_{H}\right) \\
q_{H X} & =\frac{c_{F}-c_{H}}{2 t} \\
q_{F X} & =\frac{a-2 c_{F}+c_{H}}{3 t} \\
q_{F} & =a-c_{F} .
\end{aligned}
$$

If $c_{H} \geq c_{F}$ exports of country $H$ to $F$ are negative. To make them non negative we should provide firm $H$ with a subsidy per unit of output $\tau$ as follows:

$$
\tau \geq\left|\frac{c_{F}-c_{H}}{2 t}\right| .
$$

As it can be seen the subsidy depends directly on the gap between the costs of the two rivals and the subsidy decreases as transport costs decrease $(t \rightarrow 1)$. If country $H$ objective is to let the firm export the same amount of $F$ the subsidy may be found first by equating $q_{F X}$ and $q_{H X}$ and solving in terms of $c_{H}$ :

$$
q_{F X}=q_{H X} \text { if } c_{H}^{s}=\frac{1}{5}\left(7 c_{F}-2 a\right) \leq c_{F}
$$

where $c_{H}^{s}$ is the cost of $H$ that makes for an export equal to that of $F$. Therefore, if $c_{H}=c_{F}$, the subsidy that lets the profit seeker export as much as the stateowned firm must be equal to

$$
c_{F}-c_{H}^{s}=c_{F}-\frac{1}{5}\left(7 c_{F}-2 a\right)=\frac{2}{5}\left(a-c_{F}\right) .
$$

Then the export subsidy for the $H$ firm to export as much as the stateowned firm should be

$$
\tau_{E X}=\frac{2}{5} a-c_{F}
$$


As it can be seen it should be calibrated to the size of the market (increase as the size increases) and to the cost of the rival (if the rival becomes more efficient the subsidy for $H$ must increase).

We may design subsidies or other trade policy tools bound to pursue alternative public goals. In the above proposition we have just provided one instance of a policy measure that could be adopted by a government of a country whose profit seeking firm is foreclosed abroad by a foreign state owned firm. If the government wants the domestic firm to export as much as the foreign rival it must subsidize the domestic profit seeker with a per unit production subsidy that is directly proportional to the size of the market and inversely to the cost of the rival.

We have presented just an example of an (open) trade policy that is carried out to counteract a foreign country (disguised) trade policy that gives rise to domestic market foreclosure due to the presence of a stateowned firm. Many other policy choices could be designed to counteract the trade advantage that a stateowned firm shows as its domestic market may be somehow protected. We leave an extensive analysis of this issue for a next paper.

\section{Conclusions}

Nowadays most trade policies are not easy to detect and are hardly measurable. Many current international trade disputes are embedded in this problem. Some issues gravitate around the role of firms which are partly or entirely under public control. It seems that in certain cases, the trade policies that some countries (China, the US and the EU) are using are somehow "delegated" to firms whose strategies and ownership structure are part of the export promotion policies that countries adopt. Stateowned firms may be one important vehicle of this endevour in countries with a strong presence of the state in the economy such as China. Surprisingly enough, traits of the Chinese economy are replicated in several market economies especially as far as the use of stateowned companies (or quasi state owned) is concerned. For instance in France the government has a controlling stake (some 20\%) in the car manufacture Renault-Nissan, while in Germany the giant Volkswagen is under the control of local states (Laender). In China state owned firms which are strong exporters, cover a large chunk of the economy ranging 
from one fourth to one third (according to some official data go beyond that level). We have seen that there may be a tendency for state firms to make the entrance in the domestic market by foreign firms hard. We termed this strategy as one of (partial) foreclosure. This is a radical mode of behaviour coming from a simple theoretical model which is not entirely general and it is based on a Cournot mode of interaction in oligopoly. A less extreme outcome emerges in a Bertrand framework where we end up with "partial foreclosure", i.e., a market price lower at home than abroad. Anyway that occurs when a state owned firm faces competition from a foreign profit seeking rival. This outcome is consistent with the anedctotal observation that for some goods the domestic price is significantly lower than the export price. This is the opposite of dumping but it could be damaging as much or more than sheer dumping, not in terms of traditional welfare criteria, but in terms of asymmetric competition and market access.

A second related question touches economies of scale. Here the issue is not strictly associated to state owned firms, yet to size of countries. We have gone through increasing returns to scale at the firm level adopting the solution criterion that each firm sets the price equal to average cost at home charging the entire fixed cost on the domestic balance sheet. The firm exports and maximizes profits on the foreign market selling the quantity that corresponds to the equalization of marginal revenue to marginal cost. This behavioural assumption is not general but it may provide a good representation of reality. The result is traditional dumping since the export price set by each firm is lower than the domestic price. This kind of dumping may be made larger as the size of countries differ. The firm from the larger country sells abroad at a lower price. However, the larger market represents an opportunity for the firm of the smaller country which can compensate the small size of the domestic market. This opportunity requires the large country to be effectively open. Otherwise, in the presence of increasing returns to scale the large country may have an "exorbitant" competitive advantage.

On the basis of these conclusions proper trade policies could be based only on a piecemeal approach suited to specific circumstances and firm strategies. Sheer antidumping or compensative-safeguard measures may not be useful. In the case of market foreclosure induced by a stateowned foreign rival a subsidy can be designed to allow the domestic profit seeking firm to export to the foreign market as much as the foreign stateowned firm. This subsidy could be result of a government wishing to guarantee reciprocity in terms of market opportunities to its firms in a foreign market foreclosed by the 
presence of a state owned firm. That is just an example of a trade policy out of many possible actions that may be undertaken by a government aiming to provide industrial support to domestic firms on foreign markets where they may suffer asymmetric treatments.

\section{Appendix A}

We provide some simulations in Table 1 of the content of Proposition.

\section{Table 1}

$\begin{array}{llllll}\text { parameters } & 1 \text { st sim } & \text { 2nd sim } & \text { 3rd sim } & \text { 4th sim } & \text { 5th sim } \\ \text { a } & 10 & 20 & 20 & 20 & \\ \text { b } & 10 & = & & & \\ \text { f } & 2 & = & & & \\ \text { s } & 0.8 & = & & 0.5 \\ \text { t } & 0.7 & = & 0.5 & 0.7\end{array}$.

Table 2

$\begin{array}{lllll} & \text { 1st sim } & \text { 2nd sim } & \text { 3rd sim } & \text { 4th sim } \\ p_{H X} & 2.54 & 2.54 & & 4.22 \\ p_{F X} & 2.54 & 5.24 & & 8.54 \\ p_{H} & 3.84 & 8.10 & & 14.16 \\ p_{F} & 3.84 & 3.84 & & 6.89 \\ q_{H X} & 10.07 & 10.07 & 14.09 & 8.04 \\ q_{F X} & 10.07 & 20.80 & 29.12 & 16.27 \\ q_{F} & 0.52 & 0.52 & & 0.29 \\ q_{H} & 0.52 & 0.25 & & 0.14 \\ \pi_{F X} & 17.86 & 76.33 & & 97.27 \\ \pi_{H X} & 17.86 & 17.88 & & 23.78 \\ \pi_{F} & 0 & 0 & 0 & 0 \\ \pi_{H} & 0 & 0 & 0 & 0\end{array}$

1st Sim: symmetry, zero profit at home and fixed cost charged at home, Bertrand competition abroad. There is reciprocal dumping and sales are higher on the export market than at home. 
2nd sim: asymmetry $\mathrm{H}$ market is larger $(a=20)$ than $F(b=10)$. Same strategies as above.

\section{Appendix B}

Table B.1

Full Prices of Chinese manufacured goods in Europe and China (May 2016)

\begin{tabular}{|c|c|c|c|c|}
\hline & Huawei Mate 8 & LG Hom Bot ${ }^{8}$ & Lenovo Yoga $700(14 ")$ & Wanli Tyres 9 \\
\hline China & $\mathrm{y}_{3699} \simeq 503 E$ & $\mathrm{y}_{4498-5598} \simeq 612-762 E$ & $\mathrm{y}_{6999} \simeq 952 E$ & $\mathrm{y}_{433} \simeq 59 E$ \\
\hline $\mathrm{U}$ & ${ }_{502-583} \mathrm{E}$ & ${ }_{508} \mathrm{E}$ & ${ }_{799} \mathrm{E}$ & ${ }_{63} \mathrm{E}$ \\
\hline & Diff. $\simeq 0$ & dumping & dumping & foreclosure \\
\hline
\end{tabular}

where $\mathrm{y}=$ yuan and $\mathrm{E}=$ Euro.

\section{Appendix C}

We prove in this appendix the remark concerning the foreclosure with a differentiated Cournot framework. Demand functions, based on Singh and Vives (1983) framework, are:

$$
\begin{aligned}
p_{H} & =a-q_{H}-s t q_{F X} \\
p_{F} & =a-q_{F}-s t q_{H X}
\end{aligned}
$$

\footnotetext{
${ }^{8}$ Code VR 64701 LVMP . VR 6340LV = 4498 yuan, VR6270LVM $=5598$ yuan, VR6260LVM= 4998 yuan.

${ }^{9}$ Code 225/55R17 101 WZRXL
} 
while profits are

$$
\begin{aligned}
\pi_{H} & =p_{H} q_{H}+t p_{F} q_{H X} \\
\pi_{F} & =p_{F} q_{F}+t p_{H} q_{F X} .
\end{aligned}
$$

The consumer surplus in $\mathrm{H}$ is

$$
C S_{H}=\left(a-p_{H}\right)\left(q_{H}+t q_{F X}\right) / 2 .
$$

To get the equilibrium quantities we must solve the system

$$
\left\{\begin{array}{c}
\frac{\partial \pi_{F}}{\partial q_{F}} \\
\frac{\partial \pi_{F}}{\partial q_{F} X} \\
\frac{\partial\left(\pi_{H}+C S_{H}\right)}{\partial q_{H}} \\
\frac{\partial \pi_{H X}}{\partial q_{H X}}
\end{array}=0\right.
$$

The equilibrium variables are:

$$
q_{H X}^{*}=\frac{a}{3 s t} ; q_{F}^{*}=\frac{a}{3} ; q_{H}^{*}=a ; q_{F X}^{*}=0 ; p_{H}^{*}=0 ; p_{F}^{*}=\frac{a}{3} ; \pi_{H X}^{*}=\frac{a^{2}}{9 s} ; \pi_{F}^{*}=\frac{a^{2}}{9} .
$$

\section{References}

[1] Bauer, J.M. (2005) Regulation and state ownership: conflicts and complementarities in EU, Annals of Public and Cooperative Economics.76, p. $151-177$.

[2] Baumol, W., Panzar J. and Willig, R. (1982) Contestable markets and the theory of industry structure, New York, Harcourt Brace Jovanovich

[3] Brander J. and Krugman P. (1983) A reciprocal dumping model of international trade, Journal of International Economics, 15, p. 313-321.

[4] Corneo, G. and Jeanne, O. (1994) Oligopole mixte dans un marché commun, Annales d'économie et de statistique, 33, p.73-90.

[5] Decker, C. (2014) Modern economic regulation: an introduction to theory and practice. Cambridge, Cambridge University Press. 
[6] De Fraja, G. and Delbono F. (1990) Game Theoretic Models of Mixed Oligopoly, Journal of Economic Surveys, 4, p. 1-17

[7] Delbono, F. and Rossini G. (1992), Competition Policy vs Horizontal Merger with Public, Entrepreneurial and Cooperative Firms, Journal of Comparative Economics, 16, pp. 216 - 40.

[8] Goldberg, P.K. and Pavcnik, N. (2016) The effects of trade policy, NBER Working paper series n. 21957

[9] Helpman, E. (1984) "Increasing returns, imperfect markets, and trade theory" in: R.Jones and P.Kenen, eds. Handbook of International Economics, Vol.1, North Holland, Amsterdam.

[10] Krugman, P.A. (1980) Scale economies, product differentiation, and the pattern of trade, American Economic Review, 70, 950-959.

[11] Malueg, D. A. and Schwartz, M. (1994) Parallel Imports, Demand Dispersion, and International Price Discrimination, Journal of International Economics, v. 37, iss. 3-4, pp. 167-95

[12] Puccio Laura (2015) Granting Market Economy Status to China An analysis of WTO law and of selected WTO members' policy, European Parliamentary Research Service Members' Research Service November PE 571.325.

[13] Rossini, G. (2007) Pitfalls in private and social incentives of vertical crossborder outsourcing. Review of International Economics, 15, p. 932947.

[14] Singh, N. and X. Vives (1984), "Price and Quantity Competition in a Differentiated Duopoly", RAND Journal of Economics, 15, 546-54.

[15] Urdinez, F. and Masiero, G. (2015) China and the WTO: Will the Market Economy Status Make Any Difference after 2016? Chinese Economy, 48, p. $155-72$

[16] Zanardi, M. (2006) Antidumping: A Problem in International Trade, European Journal of Political Economy, 22, p. 591-617. 


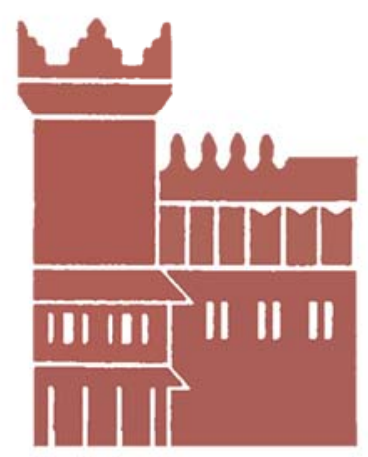

Alma Mater Studiorum - Università di Bologna DEPARTMENT OF ECONOMICS

Strada Maggiore 45

40125 Bologna - Italy

Tel. +39051 2092604

Fax +390512092664

http://www.dse.unibo.it 